\title{
Green human resource management implication on increasing productivity of small and medium enterprises
}

\author{
M. Astuti ${ }^{1^{*}}$, H.C. Wahyuni ${ }^{2}$ \\ ${ }^{1}$ Management Departement, Universitas Muhammadiyah Sidoarjo \\ ${ }^{2}$ Industrial Departement, Universitas Muhammadiyah Sidoarjo \\ *mudjiastuti@umsida.ac.id
}

\begin{abstract}
Small And Medium Enterprises (SMEs) is an economic sector that has an important role for economic growth in Indonesia. The level of employment in SMEs, resulting in the role of labor is very influential for SMEs. On the other hand, environmental issues have become an significant factor for the development of SMEs. Therefore, to ensure the sustainability of the business, it is necessary to introduce environmental and social aspects within the framework of the business. Environmental management at the operational processes of business (SMEs), has a positive influence on the sustainability of SMEs in the short term and long term. Green human resource management (Green HRM) is one tool that can be used to manage labor SMEs involving environmental aspects. This study aims to determine the implementation of green HRM in SMEs. The method used is observation and interviews conducted in three SMEs in Sidoarjo. Results showed that SMEs owners do not understand the implementation of green HRM indicated that the working patterns of employees who do not pay attention to the environment.
\end{abstract}

\section{Introduction}

Small and Medium Enterprises (SMEs) is an economic sector that has an important role for economic growth in Indonesia. One of the strong characteristics of SMEs is labor-intensive, using simple and easy-to-understand technology and capable of becoming a place for people to work (1). The high level of employment in SMEs, resulting in the role of labor is very important for SMEs. The advantages of labor compared to other factors of production in business competition strategy include: innovation ability and entrepreneurship, unique quality, special keahliaan, ability to provide different service and productivity ability that can be developed as needed.

In addition, the results of the study authors showed a positive relationship between labor and SMEs productivity but the role of labor on improving the productivity of SMEs is still low (2). Environmental management in the business operational process (SMEs), has a positive effect on MSMEs sustainability in the short and long term (3). Therefore, to ensure business sustainability, it is necessary to introduce the environmental and social aspects within the business framework (4).

In essence, green HRM is a labor management system implemented to reduce negative impacts on the environment or enhance the positive environmental impact on SMEs performance on an ongoing basis (5). HRM is the most important aspect in business management, through innovative approaches that can improve the economy, technology, socio-cultural and corporate environments (6). Moreover, 
the demands of the economy, globalization, domestic diversity and technology have prompted the company to undertake various management developments in the field of human resources of the company (7). However, on the other hand, the aspect of human resources has a lower importance when compared with technology in the form of hardware, so that in not yet a top priority in its development.

This research aims to know the implementation of green HRM in SMEs, especially in relation to productivity. Increased productivity is also one indicator of the company's success in managing all the resources it has. Creativity and innovation have a significant effect on increasing productivity, in terms of the company's more creative and innovative, more effective opportunities are created in bringing about innovative products (8).

\section{Research Methodolgy}

This research was conducted on food SMEs in Sidoarjo region. The number of samples observed was 2 SMEs. The process of data retrieval is done by observation and interview method. Observation aims to determine the real condition of SMEs, especially about the commitment of SMEs owners to environmental sustainability. The interview was conducted with the owner of SMEs, and aims to know the opinion of SMEs owners about environmental sustainability as well as the current implementation of green HRM. The green HRM variable is based on the concept of green HRM consisting of recruitment and selection, training, performance evaluation, empowerment, reward (9). Data processing is done with discrete statistics.

\section{Result and Discussion}

SMEs studied are food producers located in Sidoarjo region. The number of employees for each SMEs is 20 for SMEs know 1 and 23 for SMEs know 2. SMEs management is done by the owners, from planning to marketing.

Observations show that the commitment of SMEs owners to environmental management is still low. This is evident from the condition of the environment that is not environmentally friendly. For example, in waste disposal resulting from the tofu-making process, which consists of solid waste and liquid waste. In this process, tofu liquid waste is dumped into the river, while solid waste is used for cow food. In this process has not been done environmental management for waste generated, so the physical environment around SMEs less comfortable to see and cause unpleasant odor. For the results of interviews related to the implementation of green HRM on SMEs are presented at Table 1.

Table 1 shows that SMEs have not implemented green HRM optimally. The management focus of SMEs leads to the achievement of production and profit targets, not considering environmental elements. In fact, SMEs as one form of the company also contribute to the occurrence of environmental problems, with the pollution of waste gas, liquid and solid, so obliged to participate in solving environmental problems (10). Therefore, the implementation of green HRM on SMEs needs to be optimized immediately, with several strategic steps (5).

1. Include environmental elements in job description and job specification of each employee.

2. Incorporating environmental elements as one of the recruitment requirements, ie the company will select candidates who have commitment to the environment.

3. Incorporate environmental elements as an indicator of employee performance.

Implementation of green HRM in SMEs is expected to improve the produtivity and competitiveness of SMEs products in local/national/international markets, product competitiveness has a positive effect on SME productivity. The coding green HRM practice will be able to increase the employee's role in maintaining environmental sustainability around (11). Product competitiveness has a positive effect on SME productivity 
Table 1. Implementation of green HRM in SMEs.

\begin{tabular}{ll}
\hline Variable & Form of implementation of green HRM \\
\hline Recruitment and selection & $\begin{array}{l}\text { SMEs owners have not considered the knowledge of the environment } \\
\text { for prospective employees. Currently, the process of recruitment and } \\
\text { selection is based more on the physical capabilities of prospective } \\
\text { employees. } \\
\text { SMEs owners have not provided specific training on environmental } \\
\text { manaining } \\
\text { environment to employees. Employees will be included in } \\
\text { Government or others committed to the environment. } \\
\text { SMEs owners have not conducted a performance evaluation } \\
\text { Performance evaluasi } \\
\text { considering environmental elements. The current performance } \\
\text { evaluation is based on the fulfillment of production and profit targets. } \\
\text { Owners of SMEs have done environmental empowerment by utilizing } \\
\text { solid waste as a cow feed. Owners of SMEs also have cows that every } \\
\text { day consume food from solid waste cattle. Or other forms of } \\
\text { empowerment seen the cooperation of SMEs owners with a group of } \\
\text { cattle ranchers for the utilization of solid cow's waste. } \\
\text { Rewards provided by SMEs owners have not included environmental } \\
\text { elements. Saar, rewards given to employees more lead to achievement } \\
\text { of production targets. }\end{array}$ \\
\hline
\end{tabular}

\section{Conclusion}

Green HRM is one aspect that needs to be implemented by SMEs to increase productivity. The results show that, SMEs have not mengimplentasikan green HRM maximally. Of the 5 implementation variables considered (recruitment and selection, training, performance evaluation, empowerment, reward), at this time has been implemented empowerment on solid waste generated. This condition indicates that the owners of SMEs have not understood the importance of implementing green HRM for the development of the company.

This study is limited to observations of the implementation of green HRM in SMEs today. Furthermore, this research can be developed toward the determination of green HRM indicators in SMEs.

\section{Referensi}

1. Anggraeni FD, Hardjanto I, Hayat A. Pengembangan Usaha Mikro, Kecil dan Menengah (UMKM) Melalui Fasilitasi Pihak Eksternal dan Potensi Internal (Studi Kasus Pada Kelompok Usaha "Emping Jagung” di Kelurahan Pandanwangi Kecamatan Blimbing Kota Malang). J Adm Publik. 2013;1(6):1286-95.

2. Astuti M, Wahyuni HC, Sulistiyowati W, Ciptomulyono U, Karningsih PD. Peningkatan produktivitas usaha kecil dan menengah (UKM) berbasis technology content untuk mendukung pelaksanaan MP3EI 2011-2025. In: Peningkatan Produktivitas Usaha Kecil \& Menengah (UKM). Fakultas Ekonomi UMSIDA; 2013.

3. Zeng SX, Meng XH, Zeng RC, Tam CM, Tam VWY, Jin T. How environmental management driving forces affect environmental and economic performance of SMEs: a study in the Northern China district. J Clean Prod. 2011 Sep 1;19(13):1426-37.

4. Kondoh S, Komoto H, Kishita Y, Fukushige S. Toward a Sustainable Business Design: A Survey. Procedia CIRP. 2014 Jan 1;15:367-72.

5. Arulrajah AA, Opatha HHDNP, Nawaratne NNJ. Green human resource management practices: A review. Sri Lankan J Hum Resour Manag. 1917 Apr 22;5(1):108. 
6. $\quad$ Čech M, Yao W, Samolejová A, Li J, Wicher P. Human Resource Management in Chinese manufacturing companies. Perspect Sci. 2016 Mar 1;7:6-9.

7. Stone DL, Deadrick DL. Challenges and opportunities affecting the future of human resource management. Hum Resour Manag Rev. 2015 Jun 1;25(2):139-45.

8. Mandala A, Raharja E. Peran pendidikan, pengalaman, dan inovasi terhadap produktivitas usaha kecil dan menenga. Diponegoro J Manag. 2012;1(1):1-11.

9. Jabbour CJC, de Sousa Jabbour ABL. Green Human Resource Management and Green Supply Chain Management: linking two emerging agendas. J Clean Prod. 2016 Jan 20;112:1824-33.

10. Agan Y, Acar MF, Borodin A. Drivers of environmental processes and their impact on performance: a study of Turkish SMEs. J Clean Prod. 2013 Jul 15;51:23-33.

11. Pinzone M, Guerci M, Lettieri E, Redman T. Progressing in the change journey towards sustainability in healthcare: the role of “Green” HRM. J Clean Prod. 2016 May 20;122:201-11.

\section{Acknowledgment}

We would like to express our greatest gratitude to Kemenristek Dikti who has provided the cost for the implementation of this research through the 2017 for Applied research founding. 